\title{
Efforts To Improve Mathematic Reasoning Abilities and Self Efficacy with E-Learning Methods Based on Google Suite and Geogebra Applications on Circle Subject Grade XI MIPA SMAK PENABUR Kota Jababeka
}

\author{
Romada Rumahorbo $^{1, \text { a) }}$, Lukita Ambarwati ${ }^{2, \text { b) }}$, Lukman El Hakim ${ }^{3, \text { c) }}$ \\ ${ }^{I}$ SMAK Penabur Kota Jababeka \\ ${ }^{2,3}$ Universitas Negeri Jakarta \\ Email: a)romada.rumahorbo@gmail.com, ${ }^{b}$ lukmanunj7@gmail.com, ${ }^{c)}$ lukita@unj.ac.id
}

\begin{abstract}
The physical distancing policy to prevent the spread of the Covid 19 outbreak, which was established by WHO as a global pandemic on March 12, 2020, affects various aspects of life. Distance learning is an implementation of physical distancing policies in the field of education. The purpose of this study in general is to provide an alternative interactive distance learning method, namely by using e-Learning learning methods assisted by google suite and geogebra to improve mathematical reasoning skills and self-efficacy of class XI MIPA students of SMAK PENABUR Kota Jababeka. The subjects in this study were 6 students, three male students and three female students. The results of this research indicate that use e-Learning method based on Google Suite and Geogebra Applications can improve mathematical reasoning skills and self efficacy. The average score of students' mathematical reasoning ability test of class XI MIPA in the final test of cycle I was 63.93 with the percentage of the number of students who achieved completeness criteria was $28.12 \%$. In the final test of cycle II, the average score increased to 69.54 with the percentage was $40.63 \%$. In the final test of cycle III, the average score of students' mathematical reasoning ability test increased to 74.33 with the percentage of the number of students who achieved completeness criteria was $67.75 \%$. Meanwhile, the students' self-efficacy scores of class XI MIPA before using the e-Learning method assisted by the Google Suite and Geogebra applications, after which it has increased from 3.20 to 3.30 .
\end{abstract}

Keywords : mathematical reasoning, self efficacy, e-learning, distance learning.

\section{INTRODUCTION}

Reasoning is needed for understand mathematical objects with abstract characteristics. Mullis (2003) states that reasoning can help students to analyze, evaluate, generalize, synthesize or integrate, solve non-routine problems, and proving the argumen. Reasoning also plays an important role in drawing conclusions. This is in accordance with the Dahlan (2016) opinion, which states that "The reasoning is the process of thinking in conclusion." Reasoning is one of the most basic mental activities required in learning mathematics. Webster (in Gunhan, 2014) states that "reasoning as the ability to think coherently and logically and draw inferences or conclusions from facts known or assumed." Reasoning as the ability to think in drawing logical conclusions from several related facts that have been known to be true.

The level of student self-efficacy also affects students' ability to draw conclusions. According to Himmi (2016), self efficacy influencing decision making and actions that will be carried out. This is reinforced by Warwick (2008) that self-efficacy is a part of one's cognition that influences one's decision-making to arrange and organize actions to achieve the desired results. This statement agrees with Bandura (in Farkota, 2003), which states that a person's level of self-efficacy is very influential 
on basic things such as the following: (1) influences decision making and actions to be taken, meaning that someone tends to run something if he feels competent or confident and will avoid it if not, (2) help how far he tries to act in an activity, how long he lasts when he gets into trouble, and how flexible it is in a situation that is less favorable for him, (3) influencing thought patterns and emotional reactions means that someone who has low self-efficacy easily gives up in facing problems and tends to become stressed, depressed and has a narrow vision of what is best to solve the problem.

The reasoning abilities and self-efficacy of grade XI MIPA at SMAK PENABUR Kota Jababeka still needs to be improved. Test that consists of six the items are arranged based on six indicators of reasoning ability namely performing mathematical manipulations, drawing conclusions from several statements, finding patterns or the nature of a mathematical phenomenon to make generalizations, proposing conjectures, checking the validity of an argument, making conclusions, compile evidence, provide reasons or evidence for the correctness of the solution given to students for measure the level of students' mathematical reasoning abilities. The test results showed that the students' reasoning abilities were still low. As many as $71,875 \%$ of class XI MIPA students have low reasoning abilities. Likewise with the results of the self-efficacy questionnaire which is a modified result from the self-efficacy questionare for children by Peter Muris in his research entitled "A brief questionnaire for measuring self-efficacy in youths in 2001" which was used to measure the level of student self-efficacy. The results of the questionnaire showed that $75 \%$ of students had moderate levels of self-efficacy. Details of the pre-research results on the student's reasoning ability test and self-efficacy questionnaire can be seen in Table 1 below.

TABLE 1. The Results Of The Pre-Research Students' Reasoning Abilities And Self-Efficacy

\begin{tabular}{|c|c|c|c|}
\hline Ability & Category & Number of Students & Percentage \\
\hline \multirow{3}{*}{ Reasoning } & Low & 23 & 71,875 \\
\cline { 2 - 4 } & Moderate & 9 & 28,125 \\
\cline { 2 - 4 } Self efficacy & High & 0 & 0 \\
\cline { 2 - 4 } & Low & 2 & 6.25 \\
\cline { 2 - 4 } & Moderate & 24 & 75 \\
\cline { 2 - 4 } & High & 6 & 18.75 \\
\hline
\end{tabular}

Circle instead is one of the materials taught in mathematics for specialization in class XI MIPA even semester. In the specialization mathematics textbook for class XI (Noormandiri, 2017) it can be seen that the characteristics of circular material are combining the concepts of algebra and geometry inanalyzing circles analytically on the sub-material of circle equations, tangents to circles and the relationship between two circles. By using geogebra, students' reasoning in linking the concepts of algebra and geometry to understand circular material can be helped well. Student reasoning is also needed in linking the concepts of trigonometry and line equations and the distance of two points that have been learned in the previous class to solve problems related to the circle instead to be studied.

Choosing a learning method and the right tools in the learning process is very important to achieve learning goals. During the WFH (work from home) period which was implemented since March 2020 as a result of the physical distancing policy in an effort to break the chain of transmission of Covid 19, the use of technology played an important role in supporting the implementation of distance learning. One learning method that is suitable for improving students' reasoning skills and self-efficacy is the e-learning method. Research on the linkage of e-learning methods, reasoning and student self-efficacy has previously been conducted by Yudin Wahyudin in 2016 in his research entitled "Analysis of Mathematical Reasoning Ability and Self-Efficacy of High School Students through the Implementation of E-Learning models". This quantitative research is only limited to the use of the Mooodle application on the opportunity material.

E-learning method is a learning using computer network technology. This is in line with Wang's opinion (in Sujit, 2018) which states that "E-learning refers to the use of computer network technology, primarily over or through the internet, to deliver information and instructions to 
individuals ". The e-learning method in this study uses the Google Suite application which consists of Google Meet (to conduct conference learning both in material delivery, group discussions, presentations and questions and answers), Google calendar (as a reminder to remind students and teachers. events that have been planned or will be implemented), Google Docs (help to recap students' attendance), Google Classroom (as a forum to inform the learning agenda, teacher communication with students, submit student activity sheets to discuss in groups and collect the results of group discussions), Google Forms (as a tool for conducting surveys or questionnaires), and Moodle aplocation (to do a quiz or test).

The e-learning design used in this study uses the First Principles of Instruction approach presented by Merill (2002). The first principle of teaching according to Merill (2002) are learning is promoted when learners are engaged in solving problems that can be found in the real world (problem centric), learning is promoted when existing knowledge is activated as a foundation for new knowledge (Activation), learning is promoted when new knowledge is demonstrated to the learner (Demonstration), learning is promoted when new knowledge is applied by the learner (Application), learning is promoted when new knowledge is integrated into the learner's world (Integration). The learning design in the e-learning method can be seen in Figure 1 below.

\begin{tabular}{|c|c|}
\hline $\begin{array}{l}\text { Integration } \\
\text { Students work on reasoning problems } \\
\text { or those related to real life related to } \\
\text { material circles. Each group makes } \\
\text { their own room for discussion. }\end{array}$ & $\begin{array}{c}\text { Activation } \\
\text { Teachers and students conduct conference } \\
\text { learning at Google Meet to build new } \\
\text { concepts, namely circles using previously } \\
\text { owned concepts, namely trigonometry, } \\
\text { line equations and the distance of two } \\
\text { points. }\end{array}$ \\
\hline $\begin{array}{l}\text { Application } \\
\text { Students apply the new knowledge } \\
\text { that has been conveyed by the } \\
\text { teacher to work on circle problem } \\
\text { exercises in the Moodle application }\end{array}$ & $\begin{array}{l}\text { Demonstration } \\
\text { The teacher shows students through } \\
\text { conference learning sample } \\
\text { questions and discussions related to } \\
\text { the new material that has been } \\
\text { studied, namely circles }\end{array}$ \\
\hline
\end{tabular}

FIGURE 1. E-Learning Design

The focus of this research is "How to apply the e-Learning learning model assisted by google suite and geogebra so that it can improve students' mathematical reasoning skills and self-efficacy on circle instead?" To answer this question, researchers used the google suite application as a tool for conducting conference learning by involving four aspects, namely activation, demonstration, application, and integration in the teaching process and using the geogebra application to help students understand circles geometrically so that it can improve students reasoning skills and self-efficacy.

\section{METHOD}

This study used a qualitative class action research type (classroom action research) involving researchers, observers and 32 students of class XI MIPA at SMAK PENABUR Kota Jababeka from March to June 2020. The research subjects were six students, namely SP1 to SP6. SP1 is a female student with low criteria reasoning skills and self-efficacy, SP2 is a male student with low criteria reasoning abilities and moderate criteria self-efficacy, SP3 is a male student with low criteria reasoning abilities and moderate criteria self-efficacy, SP4 is a male student with low criteria reasoning ability and high criteria self efficacy, SP5 is a female student with both reasoning skills and self-efficacy at moderate criteria, and SP6 is a female student with moderate criteria of reasoning ability and high criteria. Focus from this research is to apply e-Learning method with Google Suite 
and Geogebra assisted so that could improve students' mathematical reasoning skills and Self Efficacy class XI MIPA at SMAK PENABUR Kota Jababeka.

During the research process, the researcher acts as the main researcher who teaches according to the research class to carry out the e-learning method as well as the action actor who acts as the designer and implementer of activities, collects and analyzes data and reports research results. The research process also involved another mathematics teacher as an observer to assist researchers in observing the learning process during the study.

The type of data collected in this research is quantitative data and qualitative data. The quantitative data is in the form of the results of the students' initial mathematical reasoning tests and the final test results of each cycle. While the qualitative data is in the form of observations of teacher and student activities, notes and documentation during learning, the results of interviews with students, the results of the questionnaire on the scale of self-efficacy at the beginning and end of the study, and video recordings.

The data collection instruments used in this study were: pre-research tests in the form of descriptions consisting of six questions and including six reasoning indicators to determine students' initial mathematical reasoning abilities, tests at the end of each cycle in the form of descriptions with the same indicators as pre-research test questions to determine students 'learning completeness in solving mathematical reasoning questions, self-efficacy attitude scale questionnaire used to determine students' self-efficacy in the learning process, student and teacher activity observation sheets to observe student and teacher activities during the learning process, field note sheets observer to determine the process of implementing learning and describe student activities during the learning process, student interview guideline sheets as student interview guides to determine student responses after learning using e-learning, documentation is carried out during the learning process using video recordings.

The distribution of research instruments to collect data on students' mathematical reasoning abilities and self-efficacy can be seen in Table 2 below.

TABLE 2. The Distribution of Research Instruments to Mathematical Reasoning Skills and Self-Efficacy

\begin{tabular}{|l|c|c|}
\hline \multicolumn{1}{|c|}{ Instrument } & $\begin{array}{c}\text { Mathematical } \\
\text { Reasoning }\end{array}$ & Self Efficacy \\
\hline Test & $\sqrt{ }$ & - \\
\hline Questionnaire & - & $\sqrt{ }$ \\
\hline Interview guidelines & $\sqrt{ }$ & $\sqrt{ }$ \\
\hline Observation sheet & $\sqrt{ }$ & $\sqrt{ }$ \\
\hline Field Note Sheet & $\sqrt{ }$ \\
\hline
\end{tabular}

The data collection technique carried out in this classroom action research uses three techniques, namely $3 \mathrm{E}$ (experiencing, inquiring, and examining). Experiencing is data collection through observation. Data collection techniques can be in the form of observation. Inquiring is a technique of collecting data through questions by researchers. Data collection techniques can be in the form of interviews, questionnaires, or tests. Examining is a data collection technique through making and utilizing notes which can be in the form of journal data, audiotapes / videotapes, or field notes.

The instrument of the final test questions for each cycle used in the study were validated by lecturers or people who are experts in mathematics. Meanwhile, data validation in this study used triangulation techniques.

Triangulation of data collection methods of mathematical reasoning ability uses test, observation, and interview methods. Meanwhile, the triangulation of student self-efficacy used a combination of questionnaire, observation, and interview methods. The triangulation flowchart of the data collection method for students' mathematical reasoning abilities and self-efficacy can be seen in Figures 2 and 3 , respectively. 


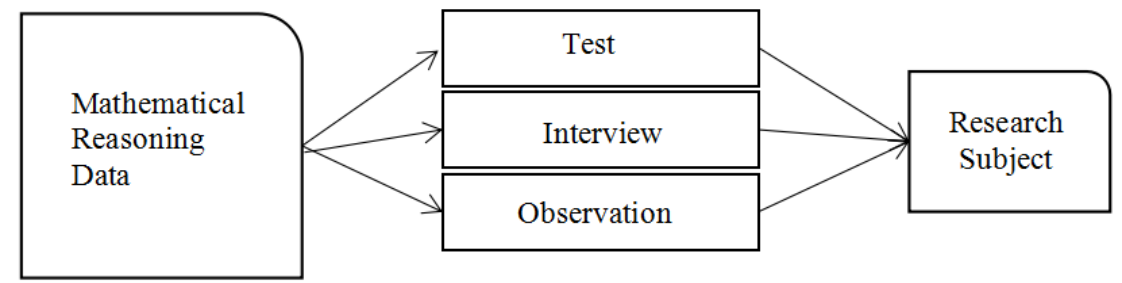

FIGURE 2. Triangulation of Data Collection Mathematical Reasoning Ability

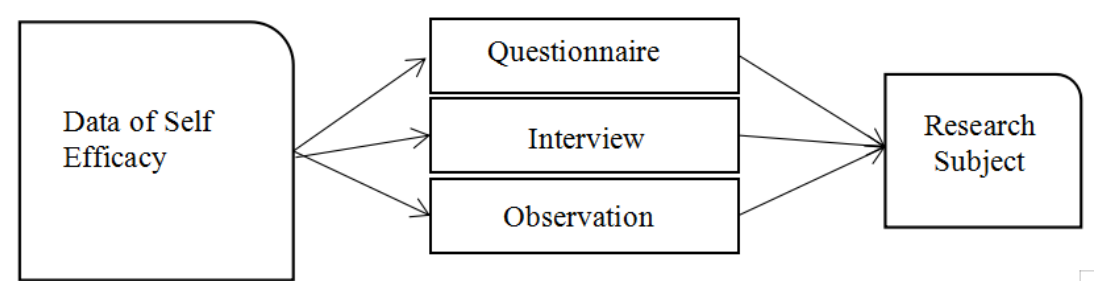

FIGURE 3. Triangulation of Self Efficacy Data Collection

Data analysis in this study used qualitative data analysis supported by quantitative data. The model used is the Miles and Huberman model which contains three stages in analyzing qualitative data, namely: the data reduction stage includes selecting, focusing and simplifying all the data that has been obtained, the data presentation stage for organizing the results of data reduction narrative in the form of text, tables or a description of student answers so that it is possible to draw conclusions and take action, the stage of drawing conclusions and verification is carried out after the data is presented to provide conclusions on the results of interpretation and evaluation and seek the validity of conclusions by testing the correctness of the data. The results of data analysis are used as the basis for determining the success of the action or for planning further actions. Verification or drawing conclusions obtained from this study is in the form of an explanation of the learning process using the e-learning method assisted by the Google Suite and Geogebra application in an effort to improve students' mathematical reasoning abilities and self-efficacy. Data analysis in the study was carried out from the beginning of the pre-study to the end of the study. The process of analyzing data is carried out by reading, studying, and understanding each data from various sources, namely the results of interviews, pre-research test results, observations recorded in field notes, and documentation results. The data analysis flow chart in this study used the Miles and Huberman stages with the stages of data reduction, data presentation to data verification. The flow chart can be seen in Figure 4 below.

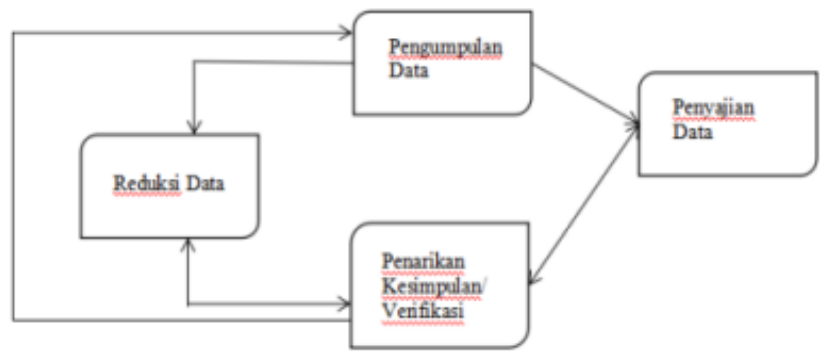

FIGURE 4. Flowchart of Miles and Huberman's Stages

\section{RESULTS AND DISCUSSION}

Qualitative data analysis is the basis for discussing the problem or focus in this study. The results of the data to be presented are divided into two parts, namely based on students' reasoning abilities and self-efficacy. 


\section{(1) Reasoning Ability}

Using e-learning methods and learning designs that contain elements of activation, demonstration, application and integrity can develop students' reasoning abilities. To start learning about new concepts in circle instead, students are given stimuli about the material or concepts they already have to build new concepts. The reasoning ability of students in finding patterns or concept relationships that they have previously had to find new concepts can be trained well. In addition, the questions or problems presented on the student's activity sheet also contain reasoning indicators. The e-learning method used in this study also pays attention to student interactions with teachers or students and students. Through conference learning using the google meet application, students can ask directly with the teacher if they have difficulty understanding the material presented by the teacher, even students can still discuss with their group of friends to equate their understanding of the new concepts they each have and solve any problems raised on the activity sheet. Video conference learning recordings that have been stored on each student's drive can be played or played back by students as needed so that students can better understand the new concepts they have built. Besides being able to improve students 'reasoning abilities, e-learning methods can train students' independence in learning. Students can more easily browse to find out the topics they have studied, assignments or problems they have worked on.

The results of the test scores for reasoning abilities on the six research subjects have increased after experiencing the learning process using the e-learning method. Table 3 and Figure 5 show the scores of each research subject on the pre-research reasoning ability test, cycle I, cycle II, and cycle III.

TABLE 3. Increasing the Reasoning Ability of Research Subjects Based on End Cycle Tests

\begin{tabular}{|c|c|c|c|}
\hline Research Subject (SP) & Cycle I & Cycle II & Cycle III \\
\hline SP1 & 79.17 & 91.2 & 95.8 \\
\hline SP2 & 83.33 & 79.2 & 95.8 \\
\hline SP3 & 62.5 & 87.5 & 91.7 \\
\hline SP4 & 75 & 70.8 & 79.2 \\
\hline SP5 & 50 & 79.2 & 75 \\
\hline SP6 & 29.17 & 63.3 & 75 \\
\hline
\end{tabular}

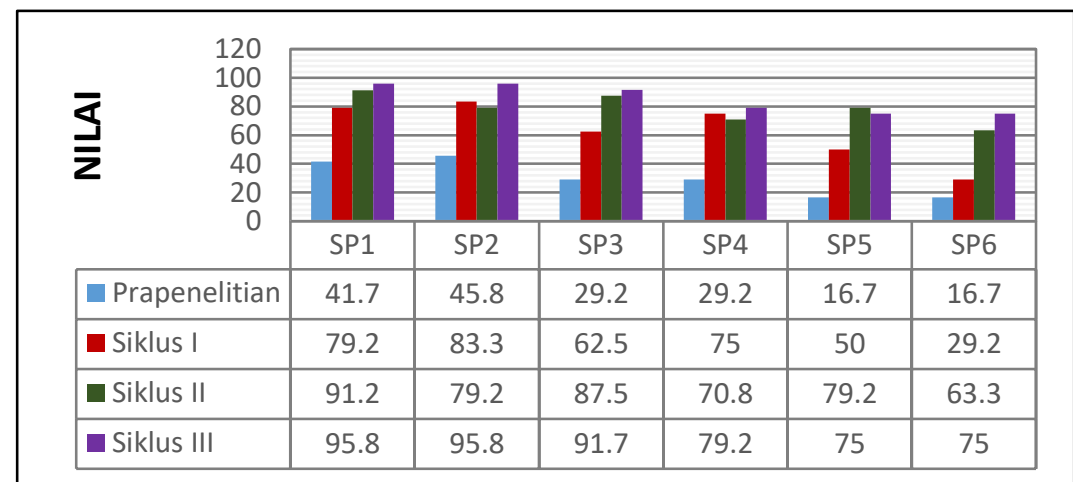

FIGURE 5. Bar Chart of Research Subject Values at The End of Each Cycle Test

Based on the table and bar chart above, it can be seen that the mathematical reasoning abilities of SP1, SP3, and SP6 have experienced a steady increase starting from cycles I, II and III. SP2, SP4 have increased from cycle I to cycle III although there was a decrease in cycle II. Meanwhile, SP5 increased from cycle I to cycle II but decreased in cycle III. Some of the factors that cause this decline are the problem of an unstable internet network, poor stamina which affects concentration and effort in studying. But overall, it can be said that the six research subjects experienced an increase in the final test results of cycle III compared to the results of the final test of cycle I. 
TABLE 4. Percentage of Improved Mathematical Reasoning Ability Class XI MIPA Students

\begin{tabular}{|l|c|c|c|}
\hline \multicolumn{1}{|c|}{ Achievement } & Cycle I & Cycle II & Cycle III \\
\hline $\begin{array}{l}\text { The percentage of the average value of students' } \\
\text { mathematical reasoning ability of class XI MIPA } \\
\text { at each final test cycle }\end{array}$ & $63.93 \%$ & $69.54 \%$ & $74.33 \%$ \\
\hline $\begin{array}{l}\text { The percentage of students who meet the } \\
\text { achievement indicators }\end{array}$ & $28.12 \%$ & $40.63 \%$ & $67.75 \%$ \\
\hline
\end{tabular}

In Table 3.1.2, it can be seen that the acquisition of the class average score on the reasoning ability test has increased. The average score of the class XI MIPA students' reasoning ability test in the pre-research was 32.16, the final test of cycle I was 63.93, the final test of cycle II was 69.54 and the final test of cycle III was 74.33 with the lowest value is 33.33 and the highest value is 100 . There was a significant increase in the average final test score of cycle III, as many as 21 students or the equivalent of $67.75 \%$ of the total students of class XI MIPA had obtained a final test score of cycle III above or equal to the KKM score of 75 . So it can be said, that there is an increase in reasoning skills in all students of class XI MIPA.

Based on the explanation above, it can be concluded that the use of e-learning methods using the google suite and geogebra can improve the reasoning skills of class XI MIPA students of SMAK PENABUR Kota Jababeka.

\section{(2) Self Efficacy}

Learning using the e-learning method assisted by the google suite application and geogebra can also increase student self-efficacy. Video conference lerning recordings owned by each student can be played back according to the needs of each student so that students feel confident in understanding the concept of circles. efficacy in students is part of self efficacy. In addition, collection of time-limited assignments in google classroom can train students' resilience and persistence which is part of self-efficacy. Doing independent questions and collecting assignments in the google classroom with a predetermined time limit can optimize students' efforts in working on and collecting assignments given on time.

In this study, a questionnaire to measure the level of student efficacy was delivered in the pre-cycle, namely before the first cycle was implemented and after the third cycle was carried out. This action is based on the idea that a person's self-efficacy has changed in a relatively long time. This is supported by the statement of Arikunto (2003), which states that formal measurement of students' affective domains cannot be done at any time because changes in student behavior cannot change at any time. The following is an explanation of the student self-efficacy questionnaire data at the pre-study and at the end of cycle III.

The self-efficacy questionnaire used in this study is a modification of self efficacy questionare for children by Peter Muris in 2001. The self-efficacy questionnaire used in this study contained 18 questions that were submitted to students to measure the level of students self-efficacy class XI MIPA at SMAK PENABUR Kota Jababeka.. The eighteen questions on the self-efficacy questionnaire are divided into three domains, namely social, academic and emotional. The social domain related to the perceived ability to manage relationships with others includes question items 2 , 6,10 , and 13. Academic domains related to the perceived ability to managing independent learning behavior, mastering academic subjects, and meeting academic expectations including question items $1,4,7,9,12,15,16$, and 18 . Emotional domains related to the perceived ability to cope with negative emotions include question items numbers $3,5,8,11,14$, and 17. 


\begin{tabular}{|c|c|c|c|c|}
\hline \multirow{2}{*}{ SP } & \multirow{2}{*}{ Questionnaire } & \multicolumn{3}{|c|}{ Domain } \\
\cline { 3 - 5 } & & Social & Academic & Emotions \\
\hline \multirow{2}{*}{ SP1 } & Pre Cycle & 4.50 & 3.75 & 3.20 \\
\cline { 2 - 5 } & Post Cycle & 3.50 & 3.63 & 3.50 \\
\hline \hline \multirow{2}{*}{ SP2 } & Pre Cycle & 3.25 & 3.25 & 3.20 \\
\cline { 2 - 5 } & Post Cycle & 4.25 & 4.00 & 4.33 \\
\hline \hline \multirow{2}{*}{ SP3 } & Pre Cycle & 3.75 & 4.25 & 3.50 \\
\cline { 2 - 5 } & Post Cycle & 4.25 & 4.50 & 4.33 \\
\hline \hline \multirow{2}{*}{ SP4 } & Pre Cycle & 3.75 & 3.25 & 2.70 \\
\cline { 2 - 5 } & Post Cycle & 4.00 & 3.50 & 3.67 \\
\hline \hline \multirow{2}{*}{ SP5 } & Pre Cycle & 3.50 & 1.88 & 1.20 \\
\cline { 2 - 5 } & Post Cycle & 2.75 & 3.00 & 2.00 \\
\hline \hline \multirow{2}{*}{ SP6 } & Pre Cycle & 3.50 & 2.13 & 2.30 \\
\cline { 2 - 5 } & Post Cycle & 3.25 & 2.63 & 3.00 \\
\hline \hline
\end{tabular}

FIGURE 6. Comparison of Research Subjects Self efficacy Scores Each Domain In the Pre-Cycle and Post-Cycle Self Efficacy Questionnaires

In Figure 6, it can be seen that SP2, SP3, and SP4 have increased self-efficacy for each domain. If you pay close attention, there are similarities between the three research subjects, namely that all three are male students. Shamim Rafique (2019) in his research entitled "Gender Differences in Corporal Punishment, Academic Self-Efficacy and Drop-Out in Secondary School Students", states that female students have higher self-efficacy in the academic domain than male students. However, in contrast to Shamim, Wahyudiati (2020) in his research entitled "Attitudes Toward Chemistry, Self-Efficacy, and Learning Experiences of Pre-Service Chemistry Teachers: Grade Level and Gender Differences", states that there is no difference in self-efficacy based on gender. Further research is needed to conclude that gender is related to one's self-efficacy.

SP1 and SP5 experienced a decrease in self-efficacy scores in the social domain. However, both of them have a tendency to have self-efficacy in the academic domain after using the e-learning method. This is due to the characteristics of using the e-learning method which emphasizes independent learning. SP1 and SP5 are accustomed to learning independently by repeating video recordings or screenshots of the material that has been studied in conference learning. SP6 has experienced a significant increase in self-efficacy in managing emotions and academic affairs after using the e-learning method in the mathematics learning process significantly.

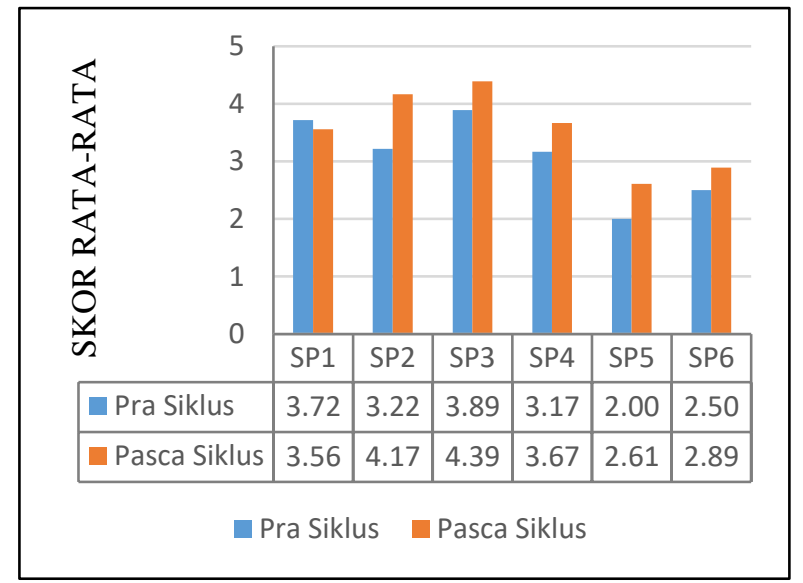

FIGURE 7. Comparison of Research Subjects Self Efficacy Questionnaire on Pre-Cycle and Post-Cycle Self Efficacy Questionnaires

Based on Figure 3.2.1, it can be said that there is an increase in students' self-efficacy in the self-efficacy questionnaire before the cycle with after the cycle or before using the e-learning method and after using the e-learning method assisted by the Google Suite and Geogebra applications. Even 
though during the Covid-19 pandemic, distance learning was required as an effort to break the covid-19 transmission chain, research subjects still had efficacy in a good category to achieve academic success. This also led to a decrease in the SP1 self-efficacy score in the social domain so that it affected the overall self-efficacy score because the boredom was too long at home in accordance with the government's recommendation to stay at home and she want to immediately return to school to socialize with friends at school so that it affects her belief to be assertive in managing social relationships.

TABLE 5. Increasing Self Efficacy of Class XI MIPA Students After Using E-Learning Methods In The Mathematics Learning process

\begin{tabular}{|c|c|c|c|c|c|c|c|c|c|c|c|c|c|c|c|c|c|c|c|}
\hline \multirow{2}{*}{ Cycle } & \multicolumn{10}{|c|}{ Question Points } \\
\cline { 2 - 17 } & 1 & 2 & 3 & 4 & 5 & 6 & 7 & 8 & 9 & 10 & 11 & 12 & 13 & 14 & 15 & 16 & 17 & 18 & \\
\hline Pre & 3.59 & 3.44 & 3.06 & 2.84 & 3.25 & 3.56 & 3.22 & 3.00 & 3.41 & 3.91 & 3.31 & 3.44 & 3.03 & 3.09 & 3.06 & 2.69 & 2.88 & 2.88 & $\mathbf{3 . 2 0}$ \\
\hline Post & 3.75 & 3.38 & 3.25 & 2.81 & 3.31 & 3.59 & 3.25 & 3.31 & 3.63 & 3.75 & 3.50 & 3.44 & 3.13 & 3.13 & 2.97 & 2.94 & 3.16 & 3.06 & $\mathbf{3 . 3 0}$ \\
\hline
\end{tabular}

Based on Table 5, it can be seen that there is an increase in student self-efficacy or self-efficacy of class XI MIPA SMAK PENABUR Kota Jababeka in the social, cognitive and emotional domains after using the e-learning method assisted by the google suite and geogebra applications in the mathematics learning process of the circle subject.

\section{CONCLUSION}

One of the efforts to improve the reasoning skills and self-efficacy of class XI MIPA students at SMAK PENABUR Kota Jababeka is to use the e-learning method with the assistance of the google suite and geogebra applications. The resarch result shows that the average score of class XI MIPA at each final cycle test and the number of students who reach or exceed the minimum completeness criteria (KKM), which is 75 has increased. The average score of students' mathematical reasoning ability test of class XI MIPA in the final test of cycle I was 63.93 with the percentage of the number of students who achieved completeness criteria was $28.12 \%$. In the final test of cycle II, the average score of the students' mathematical reasoning ability test of class XI MIPA increased to 69.54 with the percentage of the number of students who achieved completeness criteria was $40.63 \%$. In the final test of cycle III, the average score of students' mathematical reasoning ability test of class XI MIPA increased to 74.33 with the percentage of the number of students who achieved completeness criteria was $67.75 \%$. Meanwhile, the students' self-efficacy scores of class XI MIPA before using the e-Learning method assisted by the Google Suite and Geogebra applications, after which it has increased from 3.20 to 3.30. In this study, the increase resulting from each cycle was felt not optimal. This condition is due to limitations in this study, namely the internet network used by teachers and students is less stable and the eye ressistance when staring at a laptop or cellphone screen for a long time. Further research is needed to use e-learning methods with creative teaching designs so that all limitations in this study can be overcome and students do not experience boredom so that students' reasoning abilities and self-efficacy can increase optimally in carrying out distance learning.

\section{REFERENCES}

Arikunto, Suharsimi. 2003. Dasar-Dasar Evaluasi Pendidikan. Jakarta: Bumi Aksara.

Dahlan, A. 2016. The Enhancement Of Mathematical Reasoning Ability Of Junior High School Students By Applying Mind Mapping Strategyerms. Journal of Education and Practice, Vol 3.

Mullis, dan Erman Suherman. 2003. Strategi Pembelajaran Matematika Kontemporer. Bandung: JICA Universitas Pendidikan Indonesia. 
Farkota, Rhonda Maree. 2003. The Effects of a 15-minute Direct Instruction Intervention in the Regular Mathematics Class on Students' Mathematical Self-efficacy and Achievement. Thesis. Melbourne: Monash University.

Gunhan, Umay. 2014. A case study on the investigation of reasoning skills in geometry. South African Journal of Education, 34(2).

Himmi. 2016. Perbedaan Kemampuan Berpikir Kritis Matematis Dan Self Efficacy Siswa Antara Pembelajaran Berbasis Masalah Berbantuan Geogebra Dengan Pembelajaran Berbasis Masalah Berbantuan Autograph Di MAN 1 Medan. Tesis. Medan: Universitas Negeri Medan.

Merill. 2002. First Principle of Instruction. Educational, Research and Development, 50, 43 - 59.

Miles, Mattew B dan Amichael Huberman. 2007. Analisis Data Kualitatif Buku Sumber tentang Metode-Metode Baru Terjemahan Tjetjep Rohendi Rohisi. Jakarta: Universitas Indonesia.

Noormandiri, B.K. 2017. Matematika untuk SMA/MA Kelas XI Kelompok Peminatan. Jakarta: Erlangga.

Muris, P., C Meesters, F van den Berg. 2001. A Brief Questionnaire For Measuring Self-Efficacy In Youths. Journal of Psychopathology and behavioral Assessment 23 (3), 145-149.

Rafique, Shamim. 2019. Gender Diffrences in Corporal Punishment, Academic Self- Efficacy and Drop-Out in Secondary School Students. International Journal of Psycologhy and Educational Studies 6(3), 73 - 79.

Sujit, Margeruite, and Paul. 2018. E-learning, M-learning and D-learning: Conceptual Definition and Comparative Analysis. E-learning and Digital Media, 15(4), 191 - 216.

Wahyudiati, 2020. Attitudes Toward Chemistry and Learning Experiences of Pre Service Chemistry Teachers: Grade Level and Gender Differences. International Journal of Instruction 13(1), 235 254.

Wahyudin, Yudin. 2016. Analisis Kemampuan Penalaran Matematis Dan Self-Efficacy Siswa SMA Melalui Implementasi Model Pembelajaran E-Learning. Tesis. Bandung: Universitas Pasundan.

Warwick, J. 2008. Mathematical Self Efficacy And Student Engagement In The Mathematics Classroom. MSOR Connection, Vol 8 No 3, 31-37. 